\title{
Hospital-acquired Clostridium difficile infection among patients with type 2 diabetes mellitus in acute medical wards
}

\author{
${ }^{1}$ SA Hassan, ${ }^{2} \mathrm{RA}$ Rahman, ${ }^{1} \mathrm{~N}$ Huda, ${ }^{2} \mathrm{WM}$ Wan Bebakar, ${ }^{2} \mathrm{YY}$ Lee \\ ${ }^{1}$ Department of Medical Microbiology and Parasitology; ${ }^{2}$ Department of Medicine; School of Medical Sciences, Universiti Sains Malaysia, Kota \\ Bahru, Kelantan, Malaysia
}

\section{ABSTRACT}

Background: Clostridum difficile (C. difficile) infection is increasingly seen among hospitalised patients with type 2 diabetes mellitus but its rate and associated risk factors are not known. We aimed to determine the rate and characteristics of hospital-acquired C. difficile infection in subjects with type 2 diabetes mellitus admitted into acute medical wards.

Methods: Our prospective cross-sectional study involved 159 patients with established type 2 diabetes mellitus admitted into acute medical wards who developed a hospital-acquired $C$. difficile infection. Stools were tested for $C$. difficile toxins using a toxin A/B kit and a toxin A kit. Clinical features, laboratory findings, types of antibiotics, and use of a proton pump inhibitor were examined for their association with the infection.

Results: Thirteen subjects were positive for toxin A and one for toxin B. Using univariable analysis, we found that patients with type 2 diabetes mellitus and hospitalacquired $C$. difficile infection were younger (mean 53.8 years, $p=0.02$ ), had diarrhoea and abdominal pain $(p=0.00 \mathrm{l})$ but no fever. Sepsis $(p=0.02)$ and use of a proton pump inhibitor $(p=0.01)$ were more commonly implicated as the cause of the infection. Of the various types of antibiotics prescribed, carbapenem $(28.6 \%$ vs $4.1 \%, p=0.01)$ and metronidazole $(42.9 \%$ vs $19.3 \%, p=0.04)$ were significantly associated with hospitalacquired $C$. difficile infection.

Conclusions: Patients with type 2 diabetes mellitus admitted into acute medical wards and who developed hospital-acquired $C$. difficile infection have distinct characteristics.

KEYWORDS Clostridium difficile, type 2 diabetes mellitus, nosocomial, antibiotics, acute medical wards

DECLARATION OF INTERESTS No conflicts of interest declared.
Correspondence to Yeong Yeh Lee Department of Medicine, School of Medical Sciences, Universiti Sains Malaysia 16150 Kubang Kerian, Kelantan, Malaysia

tel. +6097663448 e-mail justnleeyy@gmail.com

\section{INTRODUCTION}

Clostridium difficile (C. difficile) is one of the most common nosocomial infections in recent decades, with increasing prevalence, morbidity and mortality being reported worldwide. ${ }^{-3}$ Unfortunately data on the incidence of $C$. difficile infection in Asia in particular are more limited but the available reports suggest an increasing number in countries including Singapore, Taiwan, Korea, India and Japan. ${ }^{48} \mathrm{C}$. difficile is a grampositive spore-forming bacterium, producing cytotoxin (toxin $A, B$ ) and the resulting pathology can vary from being asymptomatic to pseudomembranous colitis, a condition with high morbidity.

Some of the established risk factors for hospitalacquired $C$. difficile infection include exposure to antibiotics, use of a proton pump inhibitor, advancing age, impaired immunity (e.g. haematologic malignancies, chemotherapy) and renal disease. ${ }^{9} 10$ Type 2 diabetes mellitus (T2DM) is a chronic metabolic disease related to insulin resistance and it is associated with increased susceptibility to infections as a result of impaired immunological tolerance. Diabetes mellitus has recently been implicated as a risk factor for recurrent $C$. difficile infection."

Type 2 diabetes mellitus is highly prevalent in the Northeastern region of Peninsular Malaysia. ${ }^{12,13}$ An increasing number of hospital-acquired $C$. difficile infections have been reported among our patients with T2DM, especially in those admitted into acute medical wards, but its rate and associated risk factors are not known. A literature review found few relevant studies, thus prompting our review. We aimed to determine the characteristics of hospital-acquired $C$. difficile infection in patients with T2DM, admitted into acute medical wards. 


\section{MATERIALS AND METHODS}

\section{Study population}

We conducted a prospective cross-sectional study between August 2009 and May 2010 in a tertiary university hospital (Hospital Universiti Sains Malaysia) serving the North-eastern region of Peninsular Malaysia (State of Kelantan). The region has a population of 1.6 million with a predominance of Malay people of approximately $90 \%$. The university hospital has 700 beds and is the main referral institution within the region for the management of T2DM and its associated complications, with approximately 16 beds in acute medical wards (high dependency unit and critical care unit).

All adult patients over the age of 18-years-old, with established T2DM, consecutively admitted into the acute medical wards of the university hospital during the study period were screened for hospital-acquired $C$. difficile infection. Suspected or unconfirmed cases of T2DM and type I diabetes mellitus were excluded. Other exclusion criteria included patients with other co-morbidities known to have an increased susceptibility to $C$. difficile infection including acquired immune deficiency syndrome (AIDS), other immune-compromised states, gastrointestinal infections and inflammation.

A total of 159 out of 163 screened patients who satisfied the inclusion and exclusion criteria were recruited after providing informed consent. Clinical parameters including age, gender, symptoms, medical illnesses and infective complications associated with T2DM, type of antibiotics and proton pump inhibitor use were carefully documented in a data capture sheet. A sample of venous blood $(5 \mathrm{~mL})$ was collected from each patient to test for white cell counts, urea, creatinine level and glycosylated haemoglobin (HBAIc).

Our study was approved by the Human Ethics Committee of the Universiti Sains Malaysia.

\section{Definitions}

A diagnosis of T2DM was based on typical symptoms and a casual plasma glucose level of $\geq 11.1 \mathrm{mmol} / \mathrm{L}$, a fasting plasma glucose level of $>7.0 \mathrm{mmol} / \mathrm{L}$ or a twohour postload glucose level of $\geq 11.1 \mathrm{mmol} / \mathrm{L} .^{14} \mathrm{It}$ is the most common form, and is characterised by insulin resistance and an increased risk for microvascular and macrovascular complications. ${ }^{14} \mathrm{~A}$ patient was considered to have $C$. difficile infection for the purposes of our study when they had a positive cytotoxin assay and diarrhoea. ${ }^{15}$ The presence of either toxin A or B in the stools, confirmed using at least two different test kits, was considered positive for the cytotoxin assay. ${ }^{16}$ Diarrhoea was defined as passage of more than three loose stools within a 24-hour period with a duration of more than two days. ${ }^{15}$ A C. difficile infection was considered to be hospital-acquired when it occurred more than 48 hours after hospital admission or less than 48 hours after admission in patients who had been hospitalised for four weeks prior to the current admission. ${ }^{17}$ Exposure to any antibiotic treatment was defined as a prescription covering at least 48 hours in the last eight weeks prior to the $C$. difficile infection. Sepsis is a clinical syndrome and was defined by the presence of a systemic inflammatory response and bacteraemia from a positive blood culture. ${ }^{18}$

\section{Stool sample and toxin detection}

At least one fresh stool sample was collected from all patients included in the study. They were then stored at temperatures between $2-8^{\circ} \mathrm{C}$ in a microbiology laboratory with a dedicated storage facility. The samples were tested for the presence of toxin(s) within 72 hours; those not tested during this period were stored at $-20^{\circ} \mathrm{C}$ or below and tested within two months of collection. The presence and type of toxin(s) in the stool samples were first tested using a $C$. difficile toxin $A / B$ test kit. The single-use test kit is a membrane-type of enzyme immunoassay (EIA) allowing results to be read from a membrane, and it detects both toxins $A$ and B. ${ }^{16}$ According to the manufacturer, the test kit has a sensitivity of $86.3 \%$, specificity of $96.2 \%$ and a negative predictive value of $96.8 \%$, with reading time within 20 minutes. Stool samples tested positive were then re-tested using the $C$. difficile toxin $A$ test to confirm the presence of toxin $A$ in the stool samples. Negative samples were considered to have toxin $B$ present. The toxin $A$ test is also a form of membrane-type ElA, with a sensitivity of $90.4 \%$, specificity of $97.8 \%$ and a reading time within 30 minutes. $^{16}$

\section{Statistical analysis}

Data analyses were carried out using statistical software. All variables were reported as frequency and percentage unless otherwise stated. Univariable differences were tested using a chi-squared test or a Fisher's exact test for categorical variables and an independent t-test for continuous variables. A $p$ value of $<0.05$ was considered statistically significant for all analyses.

\section{RESULTS}

Of the 159 study patients, there were more females than males $(54.1 \%$ vs $45.9 \%)$ and the mean age (standard deviation [SD]) was 60.7 years old (II.0). In keeping with the demographic pattern within the region, ethnic Malays constituted $94.3 \%$ of the recruited patients. Fourteen out of 159 stool samples $(8.8 \%)$ tested positive for $C$. difficile using the toxin $A / B$ kit. When retested with the toxin $A$ test, 13 tested positive for toxin $A$.

Patients with T2DM and who tested positive for $C$. difficile infection were significantly younger $(p=0.02)$ but no significant difference between genders was noted 
TABLE I Characteristics of study population with a Clostridium difficile infection

\begin{tabular}{|c|c|c|c|}
\hline \multirow[b]{2}{*}{ Parameters } & \multicolumn{2}{|c|}{$\begin{array}{c}\text { Clostridium difficile } \\
\text { status }\end{array}$} & \multirow[b]{2}{*}{$p$ value } \\
\hline & $\begin{array}{l}\text { Positive } \\
(n=14)\end{array}$ & $\begin{array}{c}\text { Negative } \\
(n=\mid 45)\end{array}$ & \\
\hline Age, years, mean & $53.8(14.2)$ & $61.1(10.5)$ & $0.02^{*}$ \\
\hline \multicolumn{4}{|l|}{ Gender } \\
\hline Male & $5(35.7 \%)$ & 68 (46.9\%) & 0.43 \\
\hline Female & $9(64.3 \%)$ & 77 (53.1\%) & \\
\hline \multicolumn{4}{|l|}{$\begin{array}{l}\text { Clinical features } \\
\text { suggestive of } C D I\end{array}$} \\
\hline Fever & $5(35.7 \%)$ & $55(37.9 \%)$ & 0.87 \\
\hline Abdominal pain & $8(57.1 \%)$ & $23(15.9 \%)$ & $0.00 \mathrm{I}^{*}$ \\
\hline Asymptomatic & 0 & 26 (I7.9\%) & 0.08 \\
\hline \multicolumn{4}{|l|}{$\begin{array}{l}\text { Laboratory } \\
\text { features }\end{array}$} \\
\hline $\begin{array}{r}\text { White cell counts, } \\
\times 10^{9} / L \text {, mean }\end{array}$ & $12.6(7.1)$ & $12.6(6.2)$ & 0.98 \\
\hline Urea, mmol/L, mean & $15.8(8.2)$ & $14.2(10.3)$ & 0.56 \\
\hline $\begin{array}{r}\text { Creatinine, } \mu \mathrm{mol} / \mathrm{L}, \\
\text { mean }\end{array}$ & $\begin{array}{c}415.4 \\
(316.5)\end{array}$ & $\begin{array}{c}318.4 \\
(325.3) \\
\end{array}$ & 0.29 \\
\hline Albumin, $g / L$, mean & $30.9(8.1)$ & $31.3(7.7)$ & 0.87 \\
\hline HBAIc, \%, mean & $7.0(1.3)$ & $8.5(2.96)$ & 0.07 \\
\hline \multicolumn{4}{|l|}{$\begin{array}{l}\text { Complications of } \\
\text { diabetes mellitus }\end{array}$} \\
\hline Hypertension & $\mathrm{II}(78.6 \%)$ & $96(66.2 \%)$ & 0.35 \\
\hline $\begin{array}{r}\text { Ischaemic heart } \\
\text { disease }\end{array}$ & $3(21.4 \%)$ & $44(30.3 \%)$ & 0.49 \\
\hline $\begin{array}{r}\text { Chronic kidney } \\
\text { disease }\end{array}$ & $8(57.1 \%)$ & $56(38.6 \%)$ & 0.18 \\
\hline $\begin{array}{r}\text { Cerebrovascular } \\
\text { disease }\end{array}$ & 0 & 5 (3.4\%) & 0.48 \\
\hline \multicolumn{4}{|l|}{$\begin{array}{l}\text { Infections } \\
\text { needing } \\
\text { antibiotics }\end{array}$} \\
\hline Abscess & I (7.I\%) & $7(4.8 \%)$ & 0.71 \\
\hline $\begin{array}{r}\text { Infective } \\
\text { endocarditis }\end{array}$ & 0 & $\mathrm{I}(0.7 \%)$ & 0.75 \\
\hline $\begin{array}{r}\text { Intra-abdominal } \\
\text { infection }\end{array}$ & $2(14.3 \%)$ & 14 (9.7\%) & 0.58 \\
\hline $\begin{array}{r}\text { Infected diabetic } \\
\text { foot }\end{array}$ & I (7.I\%) & $9(6.2 \%)$ & 0.89 \\
\hline Pneumonia & $6(42.9 \%)$ & $70(48.3 \%)$ & 0.70 \\
\hline Sepsis & $5(35.7 \%)$ & $19(13.1 \%)$ & $0.02^{*}$ \\
\hline Skin infection & 0 & $15(10.3 \%)$ & 0.21 \\
\hline $\begin{array}{r}\text { Other soft tissues } \\
\text { infection }\end{array}$ & 0 & II (7.6\%) & 0.29 \\
\hline $\begin{array}{l}\text { Use of proton } \\
\text { pump inhibitor }\end{array}$ & $13(92.9 \%)$ & $85(58.6 \%)$ & $0.01^{*}$ \\
\hline $\begin{array}{l}\mathbf{n}=\text { number of cases; } \\
P \text { value }<0.05 \text { (Fisher }\end{array}$ & $\begin{array}{l}\text { ean }=\text { stand } \\
\text { exact test) }\end{array}$ & rd deviati & gnificant \\
\hline
\end{tabular}

(Table I). Besides diarrhoea, the presence of abdominal pain $(p=0.00 \mathrm{I})$ but not fever was more common among subjects with T2DM and C. difficile infection. None of the laboratory markers were helpful for differentiating either active or inactive infection (Table I). Of the various types of clinical infections identified during admission, only sepsis was significantly associated with $C$. difficile $(p=0.02)$. There was a significant usage of protonpump inhibitors among patients tested positive for $C$. difficile infection $(p=0.01)$. Only $44(27.7 \%)$ patients received just one type of antibiotic during admission, with the rest receiving two or more types. Cloxacillin (33.3\%) followed by ceftazidime $(29.6 \%)$ were the most commonly prescribed. The combination of carbapenem $(28.6 \%$ vs $4.1 \%, p=0.01)$ and metronidazole $(42.9 \%$ vs $19.3 \%, p=0.04$ ) was significantly associated with $C$. difficile infection in our study (Table 2).

\section{TABLE 2 Type of antibiotics associated with Clostridium} difficile infection

\begin{tabular}{|c|c|c|c|}
\hline \multirow[b]{2}{*}{ Antibiotics } & \multicolumn{2}{|c|}{$\begin{array}{c}\text { Clostridium difficile } \\
\text { status }\end{array}$} & \multirow[b]{2}{*}{ p value } \\
\hline & $\begin{array}{l}\text { Positive } \\
(n=14)\end{array}$ & $\begin{array}{l}\text { Negative } \\
(n=145)\end{array}$ & \\
\hline Cephalosporin & $10(71.4 \%)$ & $104(71.7 \%)$ & 0.6 \\
\hline Penicillin & $8(57.1 \%)$ & $80(50.3 \%)$ & 0.9 \\
\hline Macrolide & $3(21.4 \%)$ & $38(26.2 \%$ & 0.5 \\
\hline Carbapenem & $4(28.6 \%)$ & $6(4.1 \%)$ & $0.01^{\S}$ \\
\hline Aminoglycoside & 0 & $2(1.4 \%)$ & 0.8 \\
\hline Vancomycin & I (7.I\%) & $3(2.1 \%)$ & 0.2 \\
\hline Metronidazole & $6(42.9 \%)$ & $28(19.3 \%)$ & $0.04^{\S}$ \\
\hline Ciprofloxacin & $2(14.3 \%)$ & $16(11.0 \%)$ & 0.7 \\
\hline $\begin{array}{l}\text { Anti-tuberculosis } \\
\text { antibiotics }\end{array}$ & 0 & 5 (3.4\%) & 0.5 \\
\hline \multicolumn{4}{|c|}{$\begin{array}{l}\mathbf{n}=\text { number of cases; }{ }^{\S}=p \text { value }<0.05 \text { Fisher's exact test; } \\
\text { "antituberculosis antibiotics include isoniazid, rifampicin, } \\
\text { ethambutol and pyrazinamide in combination }\end{array}$} \\
\hline
\end{tabular}

\section{DISCUSSION}

We acknowledge from the outset that the study was limited by the small number of positive samples of $C$. difficile, which did not allow further multivariable analysis.

We found that patients with T2DM and hospitalacquired $C$. difficile infection were significantly younger than non-infected patients. In contrast, the majority of studies report that the infection occurs more frequently in older people, but diabetes mellitus was not specifically addressed. ${ }^{19}$ The reason for this difference in age is unknown but it might relate to an earlier and longer exposure to antibiotics. Abdominal pain but not fever was more significantly associated with hospital-acquired C. difficile infection in patients with T2DM. Besides diarrhoea, other clinical features consistent with $C$. difficile infection include abdominal pain, fever, leukocytosis 
and hypoalbuminemia. ${ }^{15}$ In general, fever occurs in $\sim 28 \%$ cases, abdominal pain in $\sim 22 \%$ and leukocytosis in $\sim 50 \%{ }^{20}$ In our study, with the presence of other infections and an immune-suppressed state associated with T2DM, it is probably not surprising that fever was not discriminatory for $C$. difficile infection.

White cell counts, urea, creatinine, albumin and HBAIC levels were not discriminatory for $C$. difficile infection in subjects with T2DM. Leukocytosis and hypoalbuminemia, commonly associated with $C$. difficile infection, and the absence of association in our study, is probably a result of their co-presence with T2DM-associated co-morbidities. Similarly, none of the common medical complications of T2DM were shown to make any significant difference between infected and non-infected patients. Contrary to generally accepted belief, chronic kidney disease did not appear to increase the risk of $C$. difficile infection in our study either. However, the risk may not have increased until the glomerular filtration rate decreased to $15 \mathrm{~mL} /$ min and below. ${ }^{21}$

Of the different types of severe infections associated with T2DM in acute medical wards, sepsis was the only significant risk factor associated with a hospital-acquired C. difficile infection. Sepsis tends to be more severe and hence management often involves use of multiple highdose broad spectrum antibiotics for a longer duration of time. This inevitably increases the risk for hospitalacquired $C$. difficile infection. Proton-pump inhibitor use was significantly associated with hospital-acquired $C$. difficile infection among the patients in our study, and in keeping with other reported studies, this is an established risk factor. ${ }^{22}$

Clindamycin and cephalosporins are antibiotics commonly implicated in C. difficile infection ${ }^{23}$ but any connection with diabetes mellitus is unknown. Our study indicates that carbapenem and metronidazole were possibly associated with hospital-acquired $C$. difficile infection in subjects with T2DM admitted into acute medical wards.

Our findings corroborate with a recent case-control study which reported that carbapenem was more commonly implicated with $C$. difficile infection in hospitalised subjects, even though diabetes mellitus was not specifically investigated in this study. ${ }^{24}$ The reasons for this are unknown. One early study reported that three out of ten patients were reported to have developed a $C$. difficile infection particularly when a highdose of imipenem/cilastatin of I $g$ was given every six hours. ${ }^{25}$ Furthermore, chronic renal disease (which is common in people with diabetes mellitus) can potentially increase the toxicity of antibiotics due to a reduced excretion rate. Evidence suggests that patients with diabetes mellitus are particularly vulnerable to bowel infections as a result of altered gut microbiota composition and volume ${ }^{26}$ and this is even more likely with the use of luminal antibiotics. Metronidazole, in oral form, is commonly used in the treatment of $C$. difficileassociated colitis. In our study, however, metronidazole was prescribed before a diagnosis of $C$. difficile infection was made. Recent reports indicate that the resistance of C. difficile to metronidazole is increasing, ${ }^{27}$ particularly in tropical countries, where it is commonly used as an antiparasite agent. A recent study indicated that diabetes mellitus and sepsis are significant risk factors which explains the failure of metronidazole treatment in $C$. difficile infection. ${ }^{28}$ Based on this information, vancomycin appears to be the better choice for treatment of $C$. difficile infection in patients with T2DM and sepsis.

There were limitations in our study. Sample size was partly limited by recruiting subjects with only T2DM admitted into acute medical wards. Exclusion criteria, an inability to provide consent (due to confusion, severe illness etc.) or stool samples were other limiting factors. As more than $70 \%$ of our study patients received two or more antibiotics, it was difficult to fully evaluate the effect of interactions between them. Patients with type I diabetes mellitus were not included in the study but the same results might be applicable since both conditions are associated with increased susceptibility to infections.

\section{CONCLUSION}

Hospital-acquired C. difficile infection was more common in younger subjects with T2DM admitted into acute medical wards, especially in the presence of sepsis and the use of carbapenem and metronidazole were associated with a higher risk of infection.

While we accept that there were some limitations in our study, we still believe that the information we gathered should be used for future research and ultimately improvements in patient care.

\section{Acknowledgements}

This study was supported by a Universiti Sains Malaysia short-term grant. We would like to thank all of the patients who took part. A special thanks also to all laboratory staff and nurses who assisted in the research. 


\section{REFERENCES}

I Kachrimanidou M, Malisiovas N. Clostridium difficile infection: a comprehensive review. Crit Rev Microbiol 20I I; 37: 178-87. http:// dx.doi.org/I0.3 I09/I04084IX.201 I.556598

2 Dubberke ER, Butler AM, Yokoe DS et al. Multicenter study of Clostridium difficile infection rates from 2000 to 2006. Infect Control Hosp Epidemiol 2010; 31:1030-7. http://dx.doi.org/I0.1086/656245

3 Kuijper EJ, Coignard B, Tull P et al. Emergence of Clostridium difficileassociated disease in North America and Europe. Clin Microbiol Infect 2006; I2 Suppl 6:2-I8. http://dx.doi.org//0.IIII/ j. I469-069I.2006.0I580.x

4 Koh TH, Tan AL, Tan ML et al. Epidemiology of Clostridium difficile infection in a large teaching hospital in Singapore. Pathology 2007; 39:438-42. http://dx.doi.org//0.1080/003 /302070/444507

5 Hsu MS, Wang JT, Huang WK, et al. Prevalence and clinical features of Clostridium difficile-associated diarrhea in a tertiary hospital in Northern Taiwan. J Microbiol Immunol Infect 2005; 39:242-8.

$6 \mathrm{Kim}$ J, Pai H, Seo MR et al. Epidemiology and clinical characteristics of Clostridium difficile infection in a Korean tertiary hospital. J Korean Med Sci 20II; 26:I258-64. http://dx.doi.org/I0.3346/ jkms.20II.26.10.1258

7 Ingle M, Deshmukh A, Desai D et al. Pevalence and clinical course of Clostridium difficile infection in a tertiary-care hospital: a retrospective analysis. Indian J Gastroenterol 201 I; 30:89-93. http:// dx.doi.org/ I0.1007/s I 2664-0 I I-0097-5

8 Iwashima $\mathrm{Y}, \mathrm{Nakamura} \mathrm{A}$, Kato $\mathrm{H}$ et al. A retrospective study of the epidemiology of Clostridium difficile infection at a university hospital in Japan: genotypic features of the isolates and clinical characteristics of the patients. J Infect Chemother 2010; 16:329-33. http://dx.doi.org//0.1007/s I0156-010-0066-4

9 Loo VG, Bourgault AM, Poirier L et al. Host and pathogen factors for Clostridium difficile infection and colonization. N Eng J Med 20I I; 365: 1693-703. http://dx.doi.org//0.1056/NEJMoa I 012413

10 McFarland LV, Mulligan ME, Kwok RY et al. Nosocomial acquisition of Clostridium difficile infection. N Engl J Med 1989; 320:204-10. http://dx.doi.org/I0.1056/NEJMI 9890I263200402

II Shakov R, Salazar RS, Kagunye SK et al. Diabetes mellitus as a risk factor for recurrence of Clostridium difficile infection in the acute care hospital setting. Am J Infect Control 201 I; 39:194-8. http://dx. doi.org/10.1016/j.ajic.2010.08.017

12 Mustafa N, Kamarudin NA, Ismail AA et al. Prevalence of abnormal glucose tolerance and risk factors in urban and rural Malaysia. Diabetes Care 20I I; 34: I362-4. http://dx.doi.org/I0.2337/dc I I-0005

I3 Mafauzy M, Mokhtar N, Mohammad WB et al. Diabetes mellitus and associated cardiovascular risk factors in north-east Malaysia. Asia Pac J Public Health 1999; II:16-9. http://dx.doi.org/I0.II77/ I0105395990II00104

14 American Diabetes Association. Diagnosis and classification of diabetes mellitus. Diabetes Care 2009; 32 Suppl I:S62-7. http:// dx.doi.org/10.2337/dc09-S062

15 Anand A, Bashey B, Mir T et al. Epidemiology, clinical manifestations, and outcome of Clostridium difficile-associated diarrhea. Am J Gastroenterol 1994; 89:519-23.
16 Crobach MJ, Dekkers OM, Wilcox MH et al. European Society of Clinical Microbiology and Infectious Diseases (ESCMID): data review and recommendations for diagnosing Clostridium difficileinfection (CDI). Clin Microbiol Infect 2009; I5:1053-66. http://dx. doi.org/I0.IIII/j.I469-069I.2009.03098.x

17 Garner JS, Jarvis WR, Emori TG et al. CDC definitions for nosocomial infections, 1988. Am J Infect Control 1988; 16:128-40. http://dx.doi.org/I0.1016/0196-6553(88)90053-3

18 Levy MM, Fink MP, Marshall JC et al. 200I SCCM/ESICM/ACCP/ ATS/SIS International Sepsis Definitions Conference. Crit Care Med 2003; 3I:I250-6. http://dx.doi.org/I0.1097/0I.CCM.0000050454 01978.3B

19 Morrison RH, Hall NS, Said M et al. Risk factors associated with complications and mortality in patients with Clostridium difficile infection. Clin Infect Dis 20I I; 53: I 173-8. http://dx.doi.org//0.1093/ cid/cir668

20 Bartlett JG, Taylor NS, Chang $T$ et al. Clinical and laboratory observations in Clostridium difficile colitis. Am J Clin Nutr 1980; 33:252I-6.

2I Eddi R, Malik MN, Shakov R et al. Chronic kidney disease as a risk factor for Clostridium difficile infection. Nephrology (Carlton) 2010; I5:47 I-5. http://dx.doi.org/ I0. I I I I/j. I440- I797.2009.01274.x

22 Dial S, Alrasadi K, Manoukian $\mathrm{C}$ et al. Risk of Clostridium difficile diarrhea among hospital inpatients prescribed proton pump inhibitors: cohort and case-control studies. CMAJ 2004; 171:33-8. http://dx.doi.org//0.1503/cmaj. 1040876

23 Blondeau JM. What have we learned about antimicrobial use and the risks for Clostridium difficile-associated diarrhoea? J Antimicrob Chemother 2009; 63:238-42. http://dx.doi.org// 0.1093/jac/dkn477

24 Baxter R, Ray GT, Fireman BH. Case-control study of antibiotic use and subsequent Clostridium difficile-associated diarrhea in hospitalized patients. Infect Control Hosp Epidemiol 2008; 29:44-50. http://dx.doi.org// 0.1086/524320

25 Zajac BA, Fisher MA, Gibson GA et al. Safety and efficacy of highdose treatment with imipenem-cilastatin in seriously ill patients. Antimicrob Agents Chemother 1985; 27:745-8. http://dx.doi. org/I0.I I28/AAC.27.5.745

26 Musso G, Gambino R, Cassader M. Obesity, diabetes and gut microbiota: the hygiene hypothesis expanded? Diabetes Care 2010; 33:2277-84. http://dx.doi.org//0.2337/dcl0-0556

27 Musher DM,Aslam S, Logan N et al. Relatively poor outcome after treatment of Clostridium difficile colitis with metronidazole. Clin Infect Dis 2005; 40: I586-90. http://dx.doi.org/I0.I086/4303 I I

28 Jung KS, Park JJ, Chon YE et al. Risk factors for treatment failure and recurrence after metronidazole treatment for Clostridium difficile-associated diarrhea. Gut Liver 2010; 4:332-7. http://dx.doi. org//0.5009/gnl.2010.4.3.332 